\title{
TEKNIK PENGOLAHAN CITRA PENGUKURAN BESARAN TEGANGAN REGANGAN PLAT PERSEGI DENGAN METODE MOIRE' SEBAGAI SALAH SATU ALTERNATIF PENGUKURAN DALAM DESAIN INDUSTRI MANUFAKTUR
}

\author{
Hidayat A. Marlang \\ Staf Pengajar Jurusan Desain Politeknik Negeri Samarinda \\ E-mail: hidayatmarlang75@gmail.com
}

\begin{abstract}
Moire method is one of alternative method that can be choosen in the stress-strain measurements because it is simple and does not require sophisticated equipment nor expensive with results that is accurate enough. The object of this research is a square plate clamped all edges and given load in the middle of the plate with various value. Material deformation produced moire patterns in the form of dark-light pattern (fringes) and the image have captured using a digital camera.The image of moire pattern from digital camera then processed by MATLAB using image processing tool. Furthermore, the results processed as binary images or treshold to get a clearly visible moire pattern. Finally, stress obatined from MATLAB by using image processing tool was compared with the numerical methods. The difference obtained at average 6\% for the three types of loading and at average $8.8 \%$ with the numerical method.
\end{abstract}

Keyword: eksperimen, fringe, metode Moire, stress-strain

\begin{abstract}
ABSTRAK
Metode Moire menjadi pilihan dalam pengukuran perpindahan/deformasi karena lebih mudah dan tidak memerlukan peralatan yang canggih dan mahal dengan hasil yang cukup akurat. Sebagai obyek penelitian adalah plat bujursangkar yang dijepit disemua sisinya dan diberi beban terpusat ditengah-tengahnya dengan besar yang bervariasi. Pengolahan pola gelap-terang (fringes) hasil kamera digital atau images processing dilakukan dengan software MATLAB. Sebagai pembanding digunakan metode analitis dan numerik. Hasil eksperimen diperoleh melalui software MATLAB menunjukkan bahwa medan stress yang dihasilkan oleh software melalui image processing dibandingkan dengan metode analitis terdapat perbedaan rata-rata $6 \%$ untuk tiga jenis pembebanan dan 8,8\% antara metode moire dengan numerik
\end{abstract}

Kata kunci: moire, eksperimen, matlab 
Vol. 1, No. 1, Oktober 2013

\section{PENDAHULUAN}

Perilaku deformasi suatu material adalah terjadinya perubahan bentuk dari material tersebut akibat adanya pembebanan atau perubahan temperatur sehingga bisa menyebabkan terjadinya patah pada material tersebut. Pengamatan deformasi merupakan hal yang sangat penting dalam mendesain suatu material atau penggunaannya dalam suatu konstruksi.

Strain atau regangan diukur untuk mengetahui besarnya deformasi pada saat terjadinya tegangan mekanik sehingga didapat besaran gaya yang terjadi seperti beban ataupun tegangan. Selain itu juga digunakan untuk memperoleh nilai keamanan/kekuatan suatu bahan atau suatu elemen struktural yang mengandung bahan tersebut.

Gaya yang diberikan pada suatu benda logam (material ferrit/konduktif), selain menimbulkan deformasi bentuk fisik juga menimbulkan perubahan sifat resistansi elektrik benda tersebut. Dalam hal ini, dengan menempelkan jenis material tersebut pada suatu benda uji (specimen) menggunakan suatu perekat yang isolatif terhadap arus listrik, maka material tadi akan menghasilkan adanya perubahan resistansi yang nilainya sebanding terhadap deformasi bentuknya. Karena adanya kesebandingan tersebut maka dapatlah dikatakan material ini sebagai sensor. Sensor/material inilah yang disebut strain gauge.

Kata "moiré" (baca: MWAREH) bukanlah nama seseorang, tetapi berasal dari bahasa Prancis yang berarti berair. Pola moiré adalah pola gelap terang atau frinji yang terbentuk karena adanya penumpukan (overlapping) dua buah kisi (grating). Sedangkan penumpukan kedua buah kisi tersebut dikenal dengan teknik moiré.
Tujuan

Tujuan dari penelitian ini adalah memperoleh besaran deformasi (defleksi) yang dialami plat oleh pembebanan terpusat dan membandingkan dengan hasil analitis dan numeris.

\section{KERANGKA TEORI}

Pola moiré merupakan sebuah konfigurasi yang dihasilkan dari superposisi dua atau lebih pola kisi dengan kandungan intensitas gelap terang dengan intensitas gelap terang yang periodik. Lebar garis gelap dan lebar antar garis atau garis terang biasanya sama, namun dalam beberapa kasus bisa berbeda. Tetapi dalam hal ini akan di asumsikan bahwa bahwa kisi di buat dari sistem garis gelap dan terang dengan lebar sama. Pola kisi ini dapat berbentuk garis, lingkaran dan sebagainya. Namun yang lebih umum di aplikasikan adalah kisi garis karena paling sederhana untuk dianalisa.

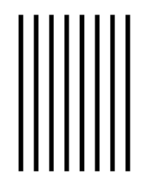

(a)

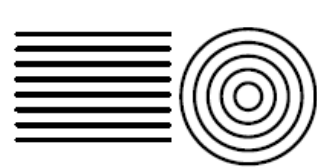

(b)

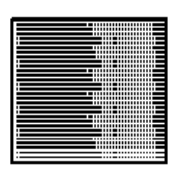

(d)
Gambar 1.

Beberapa contoh kisi pembentuk pola moiré (a). Kisi garis vertikal, (b). Kisi garis horisontal, (c) kisi berbentuk lingkaran, (d). kisi berbentuk dot

Efek dari pola moiré ini pertama kali diturunkan secara matematis oleh Dr. G. Oster pada tahun 1963 untuk keperluan pengukuran [6]. Sebuah kisi yang ditunjukkan dalam koordinat Cartesian seperti pada gambar terdiri dari garis-garis berarah vertikal dengan jarak antara garis adalah $\mathrm{a}_{1}$. Pada gambar di bawah terlihat bahwa $i_{1}$ menyatakan indeks 
Hidayat A. Marlang, Teknik Pengolahan Citra Pengukuran Besaran Tegangan Regangan Plat Persegi Dengan Metode Moire' Sebagai Salah Satu Alternatif Pengukuran Dalam Desain Industri Manufaktur

garis dan $\mathrm{L}_{1}$ memberikan jarak titik potong garis ke 0 terhadap titik asal.

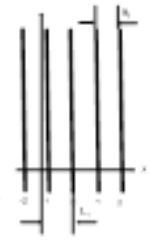

Gambar 2.

Dimensi pada sebuah pola kisi yang berbentuk garis

Maka persamaan yang menunjukkan garisgaris indeks ke-n pada gambar di atas adalah:

$$
\mathrm{x}=\mathrm{L}_{1}+\mathrm{i}_{\mathrm{n}} \cdot \mathrm{a}_{1}
$$

Dapat dilihat pada gambar 3 selanjutnya menunjukkan bahwa kisi garis vertikal tadi di putar ke kiri (berlawanan arah jarum jam) dengan besar sudut adalah $\alpha$ dengan indeks garis $i_{2}$, jarak perpotongan garis ke-0 dengan sumbu $x$ terhadap titik asal $(0,0)$ dinyatakan dengan $L_{2}$.

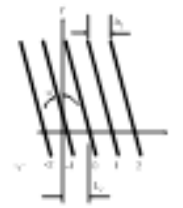

Gambar 3.

Kisi yang diberi kemiringan dengan sudut sebesar a

Dari gambar 3 maka diturunkan sehingga dapat diperoleh persamaan garis-garis adalah:

$$
\mathrm{y}=\frac{-\left(\mathrm{x}-\mathrm{L}_{2}\right) \cos \alpha+\mathrm{i}_{2} \mathrm{a}_{2}}{\sin \alpha}
$$

[2]
Seperti yang telah di uraikan di atas bahwa untuk mendapatkan efek moiré maka dua buah kisi disuperposisikan sehingga akan tampak sebuah pola baru yang bisa dilihat sebagai garis putus-putus seperti terlihat pada gambar 4

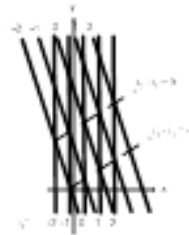

Gambar 4.

Superposisi dari dua pola kisi yang menghasilkan pola moiré

Gambar 4 memperlihatkan pola moiré dengan superposisi dua kisi dengan sudut $\alpha$, persamaan yang memenuhi posisi gambar di atas adalah:

$$
\mathrm{i}_{2}-\mathrm{i}_{1}=\mathrm{i}_{\mathrm{m}} \quad \mathrm{i}_{\mathrm{m}}=\ldots,-1,0,1 \ldots
$$

Dengan mensubstitusikan persamaan [1] dan [2] ke dalam persamaan [3] maka akan diperoleh:

$$
\mathrm{i}_{\mathrm{m}}=\frac{\mathrm{x}-\mathrm{L}_{1}}{\mathrm{a}_{1}}-\frac{\left(\mathrm{x}-\mathrm{L}_{2}\right) \cos \alpha+\mathrm{y} \sin \alpha}{\mathrm{a}_{2}}
$$

sehingga memberikan persamaan garis moiré sebagai berikut:

$$
y=\frac{x\left(\frac{a_{2}}{a_{1}}-\cos \alpha\right)-L_{1} \frac{a_{2}}{a_{1}}+L_{2} \cos \alpha-i_{m} a_{2}}{\sin \alpha}
$$

Sudut kemiringan garis moiré terhadap sumbu x berdasarkan persamaan [2-5] adalah sama dengan:

$$
\beta=\arctan \left(\frac{\frac{a_{2}}{a_{1}}-\cos \alpha}{\sin \alpha}\right)
$$


yang letaknya ditunjukkan dalam gambar 5.

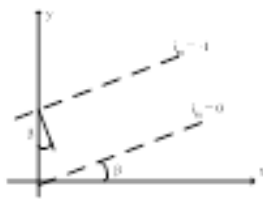

Gambar 5.

Sudut kemiringan garis moiré yang terbentuk

Jarak antara dua titik potong yang berurutan dengan sumbu y diberikan oleh:

$$
\mathrm{y}_{\mathrm{im}-1}-\mathrm{y}_{\mathrm{im}}=\frac{\mathrm{a}_{2}}{\sin \alpha}
$$

Dan gambar 5 menunjukkan bahwa jarak antar spasi moiré adalah:

$$
\mathrm{s}_{\mathrm{m}}=\left(\mathrm{y}_{\mathrm{im}-1}-\mathrm{y}_{\mathrm{im}}\right) \cos \beta
$$

Penggabungan persamaan [6] dan [8] menghasilkan persamaan spasi moiré sebagai berikut:

$$
\mathrm{s}_{\mathrm{m}}=\frac{\mathrm{a}_{1} \mathrm{a}_{2}}{\sqrt{\mathrm{a}_{1}{ }^{2}+\mathrm{a}_{2}{ }^{2}-2 \mathrm{a}_{1} \mathrm{a}_{2} \cos \alpha}}
$$

Pada teknik bayangan moiré digunakan selembar kisi garis yang diposisikan di depan obyek dan pararel terhadap bidang obyek. Kisi tersebut diterangi oleh sumber cahaya di titik S sehingga muncul pola garis yang terproyeksi pada permukaan obyek, lihat gambar 2.9. Hasil interaksi antara kisi terproyeksi dan kisi asli akan memunculkan pola moiré yang diinginkan dan selanjutnya di amati dari titik pengamat P. Pengamat dapat berupa sebuah lensa kamera atau mata telanjang.

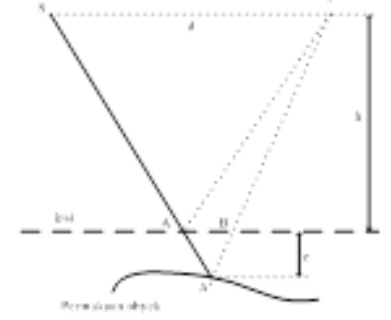

Gambar 6 .

Perangkat dalam pengukuran obyek teknik bayangan moiré

Titik S dan P yang terpisah sejauh d diposisikan pada jarak h yang sama dari bidang kisi sehingga muncul hubungan yang konsisten antara pola moiré yang terbentuk dari profil ketinggian obyek uji [2].

Pada gambar 2.9 dimisalkan titik A sebagai sebuah titik sebarang dalam kisi. Ketika titik tersebut diproyeksikan di titik A' pada obyek yang berjarak z akan muncul titik B sebagai perpotongan A'P dengan kisi.

Dengan melihat $\Delta \mathrm{SA}^{\prime} \mathrm{P}$ dan $\Delta \mathrm{AA}^{\prime} \mathrm{B}$ adalah dua buah segitiga yang sebangun maka diperoleh hubungan:

$$
\frac{\mathrm{AB}}{\mathrm{SP}}=\frac{\mathrm{A}^{\prime} \mathrm{A}}{\mathrm{A}^{\prime} \mathrm{S}}=\frac{\mathrm{z}}{\mathrm{z}+\mathrm{h}}
$$

atau

$$
\mathrm{AB}=\frac{\mathrm{zd}}{\mathrm{z}+\mathrm{h}}
$$


Hidayat A. Marlang, Teknik Pengolahan Citra Pengukuran Besaran Tegangan Regangan Plat Persegi Dengan Metode Moire’ Sebagai Salah Satu Alternatif

Pengukuran Dalam Desain Industri Manufaktur

Sebuah garis moiré akan muncul ketika titik A dan B masing-masing bertepatan dengan satu kisi garis yang berlainan. Apabila s adalah spasi kisi, dan titik A serta B terpaut sebesar $\mathrm{N}$ garis kisi, maka dapat dituliskan:

$$
(\mathrm{AB})_{1}=\mathrm{N}_{1} \mathrm{~s}=\frac{\mathrm{z}_{1} \mathrm{~d}}{\mathrm{z}_{1}+\mathrm{h}}
$$

dan untuk pasangan AB lainnya:

$$
(\mathrm{AB})_{2}=\mathrm{N}_{2} \mathrm{~S}=\frac{\mathrm{z}_{2} \mathrm{~d}}{\mathrm{z}_{2}+\mathrm{h}}
$$

Apabila besar ketinggian obyek terhadap bidang kisi sangat kecil dibandingkan jarak kisi terhadap sumber dan pengamat $(\mathrm{z}<<\mathrm{h})$, maka persamaan [2-31] dan [2-32] akan menghasilkan hubungan:

$$
\left(\mathrm{N}_{2}-\mathrm{N}_{1}\right) \mathrm{s} \approx \frac{\left(\mathrm{z}_{2}-\mathrm{z}_{1}\right) \mathrm{d}}{\mathrm{h}}
$$

Persamaan [2-33] menunjukkan korelasi sebanding antara perbedaan ketinggian dua buah titik terhadap bidang kisi dan jarak antara dua buah garis moiré. Hal tersebut merupakan kontur permukaan yang diinginkan.

Beda ketinggian yang ditunjukkan di antara $\mathrm{N}$ garis kisi dinyatakan dalam persamaan:

$$
\Delta \mathrm{z}=\frac{\mathrm{Nhs}}{\mathrm{d}}
$$

sehingga besar ketinggian terkecil yang dapat diamati $(\mathrm{N}=1)$ adalah hs/d.

\section{Penggunaan Frinji Moire Dalam Perhitungan Perpindahan}

Contoh kasus yang paling sederhana tentang keterkaitan antar frinji moire yang dihasilkan oleh superposisi dua buah kisis telah kita bahas sebelumnya dimana kisi yang satu tetap sedangkan kisi yang lainnya mengalami pergeseran.

Diasumsikan pada kisi spesimen yang semula mempunyai pitch (jarak kisi) adalah $p$ kemudian berubah menjadi $p_{1}$ akibat adanya perubahan panjang pada spesimen. Besar pergeseran (displacement) yang terjadi pada frinji ke- $n$ adalah $n p$. Dari hubungan tersebut jika kita asumsi bahwa ada $m$ buah garis pada kisi referensi yang terletak di antara dua frinji, maka:

$$
\delta=\mathrm{mp}=(\mathrm{m} \pm 1) \mathrm{p}_{1}
$$

Dari persamaan [10] diperoleh persamaan untuk menentukan jarak pitch spesimen adalah:

Jika diantara dua frinji ada $m$ buah garis pada kisi referensi, maka akan terdapat $(\mathrm{m} \pm 1)$ garis pada kisi spesimen, sehingga pada suatu jarak tertentu jika ada $n$ buah frinji maka ada $n m$ garis pada kisi referensi dan ada $n(m \pm$ 1) buah garis pada kisi spesimen [4].

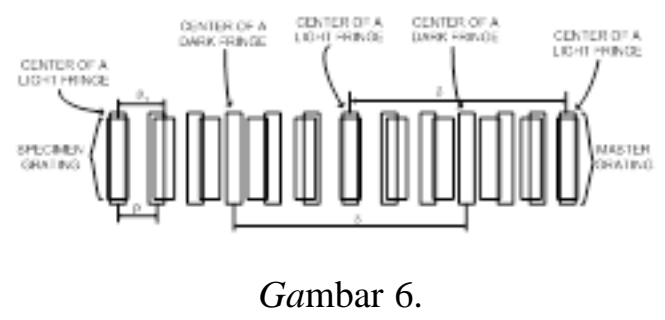

Skema frinji tanpa rotasi pada kisi

Dari persamaan [11] maka:

$$
\frac{1}{\delta}= \pm\left(\frac{1}{\mathrm{p}}-\frac{1}{\mathrm{p}_{1}}\right)= \pm \frac{\mathrm{p}_{1}-\mathrm{p}}{\mathrm{p} \cdot \mathrm{p}_{1}}
$$


Selanjutnya diperoleh:

$$
\frac{\mathrm{p}}{\delta}= \pm \frac{\mathrm{p}_{1}-\mathrm{p}}{\mathrm{p}_{1}}
$$

Dari persamaan kita lihat bahwa jika jarak pitch spesimen adalah $p_{1}$ kemudian $p$ adalah jarak pitch spesimen setelah terjadinya perubahan panjang spesimen maka nilai $\pm \frac{p_{1}-p}{p_{1}}$ adalah identik dengan nilai strain untuk kisi dengan jarak pitch adalah $\mathrm{p}_{1}$.

\section{Aplikasi Metode Ritz Pada Plat Persegi}

Energi regangan U identik dengan bending yang dialami oleh sebuah plate, dimana bisa di asumsikan bahwa kerja yang dihasilkan oleh gaya lateral pada permukaan plate $p(x, y)$ adalah:

$$
\mathrm{W}=\iint_{\mathrm{A}} \mathrm{wpdx} \mathrm{dy}
$$

Dimana A adalah luas daerah permukaan plate. Energi potensial $\Pi=\mathrm{U}-\mathrm{W}$ yaitu:

$$
\begin{aligned}
\Pi= & \frac{D}{2}\left[\int \left[\int\left[\left(\frac{\partial^{2} W}{\partial \mathrm{x}^{2}}+\frac{\hat{\partial}^{2} W}{\partial y^{2}}\right)^{2}-2(1-v)\left[\frac{\partial^{2} W}{\partial \mathrm{x}^{2}} \frac{\partial^{2} W}{\partial y^{2}}-\left(\frac{\partial^{2} W}{\partial x \partial y}\right)^{2}\right]\right] d x d y\right.\right. \\
& -\iint w p d x d y
\end{aligned}
$$

Persamaan besaran defleksi dapat diasumsikan sebagai berikut :

$$
\mathrm{w}=\sum_{\mathrm{m}=1}^{\infty} \sum_{\mathrm{n}=1}^{\infty} \mathrm{a}_{\mathrm{mn}}\left(1-\cos \frac{2 \mathrm{~m} \pi \mathrm{x}}{\mathrm{a}}\right)\left(1-\cos \frac{2 \mathrm{n} \pi \mathrm{y}}{\mathrm{b}}\right)
$$

Untuk kasus plat persegi maka nilai $\mathrm{a}=\mathrm{b}$ dengan asumsi bahwa plat tersebut di jepit pada keempat sisinya kemudian diberi beban terpusat $\mathrm{P}$ pada permukaan dengan koordinat beban adalah $\left(\mathrm{x}_{1}, \mathrm{y}_{1}\right)$ sehingga persamaan [15] menjadi:

$$
\mathrm{W}=\mathrm{P} \sum_{\mathrm{m}=1}^{\infty} \sum_{\mathrm{n}=1}^{\infty} \mathrm{a}_{\mathrm{mn}}\left(1-\cos \frac{2 \mathrm{~m} \pi \mathrm{x}_{1}}{\mathrm{a}}\right)\left(1-\cos \frac{2 \mathrm{n} \pi \mathrm{y}_{1}}{\mathrm{~b}}\right)
$$

Dimana:

$$
\begin{aligned}
& \mathrm{U}=2 \pi^{4} \mathrm{abD}\left\{\sum _ { m = 1 } ^ { \infty } \sum _ { \mathrm { n } = \alpha } ^ { \infty } \left[3\left(\frac{\mathrm{m}}{\mathrm{a}}\right)^{4}+3\left(\frac{\mathrm{n}}{\mathrm{b}}\right)^{4}+2\left(\frac{\mathrm{m}}{\mathrm{a}}\right)^{2}\left(\frac{\mathrm{n}}{\mathrm{b}}\right)^{2} \mathrm{a}^{2} \mathrm{~m}\right.\right. \\
& \left.+\sum_{\mathrm{m}=1}^{\infty} \sum_{\mathrm{r}=1}^{\infty} \sum_{\mathrm{s}=1}^{\infty} 2\left(\frac{\mathrm{m}}{\mathrm{a}}\right)^{4} \mathrm{a}_{\mathrm{mr}} \mathrm{a}_{\mathrm{ms}}+\sum_{\mathrm{r}=1}^{\infty} \sum_{\mathrm{s}=1}^{\infty} \sum_{\mathrm{n}=1}^{\infty} 2\left(\frac{\mathrm{n}}{\mathrm{b}}\right)^{4} \mathrm{a}_{\mathrm{m}} \mathrm{a}_{\mathrm{sn}}\right\}
\end{aligned}
$$

dengan kondisi $\partial \Pi / \partial \mathrm{a}_{\mathrm{mn}}=0$, maka persamaan [22] dan [23] menjadi:

$$
\begin{aligned}
& 4 \pi^{4} \mathrm{abD}\left\{\left[3\left(\frac{\mathrm{m}}{\mathrm{a}}\right)^{4}+3\left(\frac{\mathrm{n}}{\mathrm{b}}\right)^{4}+2\left(\frac{\mathrm{m}}{\mathrm{a}}\right)^{2}\left(\frac{\mathrm{n}}{\mathrm{b}}\right)^{2}\right] \mathrm{a}_{\mathrm{ma}}+\sum_{\mathrm{f}=1}^{\infty} 2\left(\frac{\mathrm{m}}{\mathrm{a}}\right)^{4} \mathrm{a}_{\mathrm{ms}}\right. \\
& \left.+\sum_{\mathrm{r}=1}^{\infty} 2\left(\frac{\mathrm{n}}{\mathrm{b}}\right)^{4} \mathrm{a}_{\mathrm{rn}}\right\}-\mathrm{P}\left(1-\cos \frac{2 \mathrm{~m} \pi \mathrm{x}_{1}}{\mathrm{a}}\right)\left(1-\cos \frac{2 \mathrm{n} \pi \mathrm{y}_{1}}{\mathrm{~b}}\right)=0
\end{aligned}
$$

Dari persamaan [20] untuk aplikasi pada plat persegi adalah dengan mensubstitusi nilai a $=\mathrm{b}$, dengan nilai $\mathrm{r} \neq \mathrm{n}$ dan $\mathrm{r} \neq \mathrm{m}$.

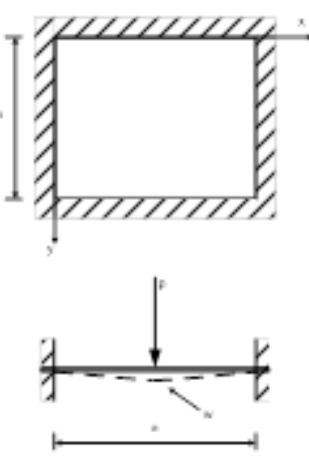

Gambar 7. Skema Plat Uji dan Arah Pembebanan

\section{METODE PENELITIAN}

Pelaksanaan eksperimen dilakukan dengan langkah-langkah sebagai berikut:

- Spesimen uji berupa baja berbentuk 
Hidayat A. Marlang, Teknik Pengolahan Citra Pengukuran Besaran Tegangan Regangan Plat Persegi Dengan Metode Moire’ Sebagai Salah Satu Alternatif Pengukuran Dalam Desain Industri Manufaktur

bujursangkar yang berukuran 150x150 cm di sablon bentuk kisi dot pada permukaannya dengan variasi ukuran mulai dari 1 mm,kemudian spesimen uji di jepit pada spesimen uji. Kemudian tumpuan jepit spesimen uji di baut untuk menjepit spesimen.

- Letakkan kisi master di atas tumpuan jepit tepat di depan spesimen uji sedemikian rupa sehingga bayangan kisi master tepat berada di atas kisi dot supaya tidak terbentuk pola moire.

- Letakkan dial indikator tepat di belakang baut beban untuk mengetahui besar displacement yang akan diberikan pada plat uji dengan terlebih dahulu mengkalibrasi penunjukan dial indikator. Nilai skala terkecil pada dial indikator tersebut adalah 0,01 mm.

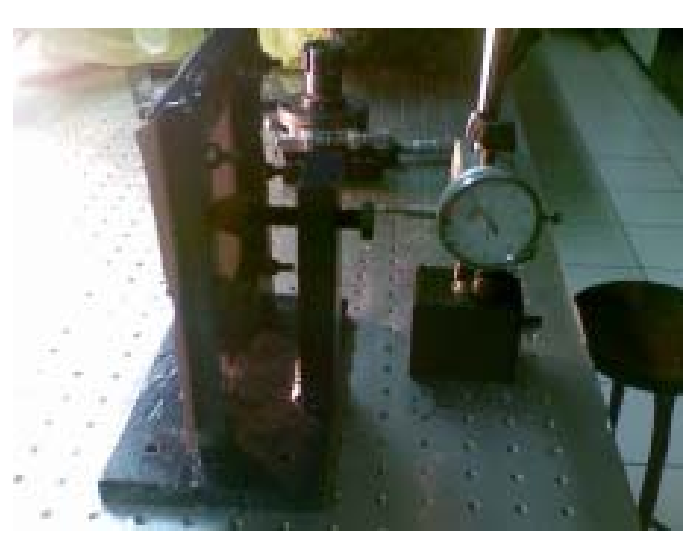

Gambar 8. Dial Indikator

- Spesimen uji diberi displacement yang bervariasi berupa pembebanan terpusat dengan memutar baut sehingga spesimen mengalami defleksi pada perpotongan diagonalnya.

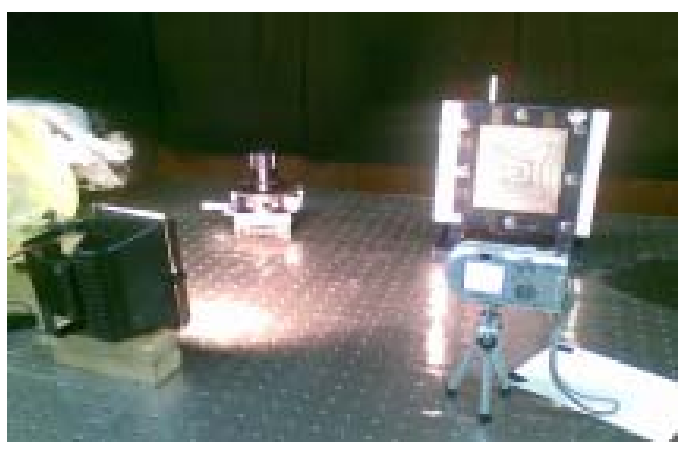

Gambar 10. Setting Peralatan Optis

- Gambar yang diperoleh pada kamera digital selanjutnya diolah oleh software

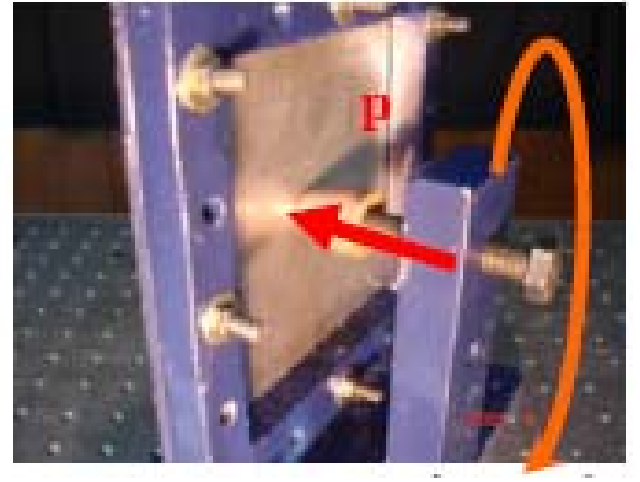

Gambar 9. Tumpuan Jepit Spesimen Uji

- Setting peralatan optis berupa kamera di depan kisi master pada jarak tertentu dan lampu halogen dengan sudut tertentu terhadap kisi master sehingga di dapatkan pola moire,jika pola moire tidak kelihatan maka lakukan setting peralatan optis tersebut hingga pola moire yang didapatkan cukup baik.

MATLAB untuk mengetahui besar jarak spasi moire yang selanjutnya dipakai untuk menentukan besar strain material akibat adanya pembebanan terpusat. 


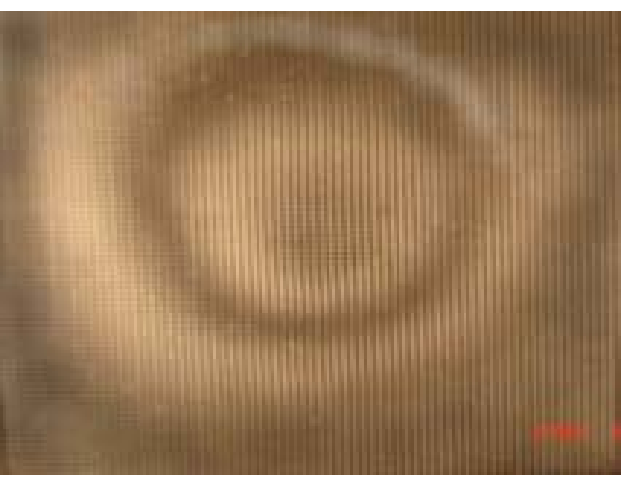

Gambar 11.

Pola Moire untuk displacement pada pusat sebesar $1.5 \mathrm{~mm}$

Pola moire yang dihasilkan untuk pembebanan pusat sebesar 1,5 mm seperti terlihat pada gambar 4.7 di atas menghasilkan semakin banyak frinji. Pada gambar terlihat pembentukan frinji terang pada pusat pembebanan sehingga jumlah frinji bertambah jika pembebanan pada pusat berupa displacement juga semakin besar.

\section{IMAGE PROCESSING}

Setelah tahap pengambilan foto telah dilakukan maka untuk mendapatkan hasil pengukuran dari foto tersebut maka dilakukan image processing dengan menggunakan software dalam hal ini peneliti menggunakan software MATLAB.

Tahap-tahap pengolahan citra yang dilakukan pada penelitian ini adalah meliputi

\section{a. Filter Dengan Menggunakan Fast Fourier Transform (FFT)}

Transformasi sangat penting untuk berbagai masalah dalam pemrosesan citra termasuk penajaman, analisis, perbaikan dan kompresi citra. Pada tahap ini diharapkan gambar yang diperoleh bisa lebih tajam karena noise yang terdapat pada citra bisa dihilangkan. Berikut ditampilkan contoh gambar yang dihasilkan oleh hasil filter image untuk pola moire dengan displacement sebesar $1,5 \mathrm{~mm}$ [5].

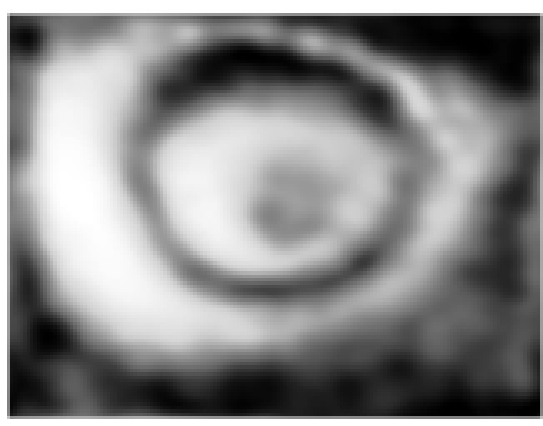

Gambar 12.

Hasil Filter Image dengan menggunakan FFT Untuk Displacement 1,5 mm

\section{b. Image Biner}

Tahap ini disebut image biner atau citra biner yaitu citra dengan nilai setiap piksel diasumsikan salah satu dari dua nilai diskrit, yaitu nilai “on” dan nilai off. Penggunaan citra biner memudahkan untuk membedakan fitur-fitur struktural, misalnya membedakan objek dari latar belakang.

Setelah image di filter dengan dengan menggunakan FFT selanjutnya dilakukan proses biner dan hasilnya seperti pada gambar 13 di bawah ini:

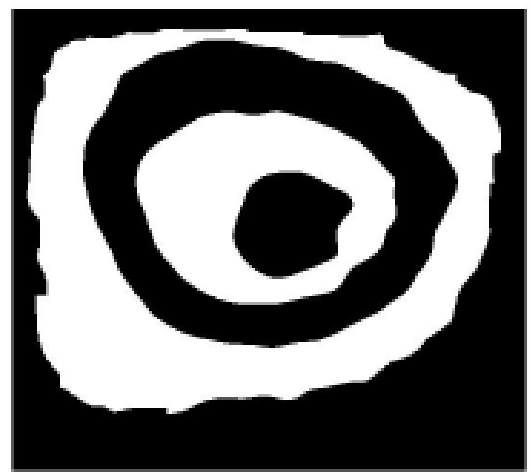

Gambar 13.

Hasil Image Biner Untuk displacement $1,5 \mathrm{~mm}$ 
Hidayat A. Marlang, Teknik Pengolahan Citra Pengukuran Besaran Tegangan Regangan Plat Persegi Dengan Metode Moire’ Sebagai Salah Satu Alternatif Pengukuran Dalam Desain Industri Manufaktur

\section{c. Image Thinned}

Setelah proses image biner menghasilkan sebuah citra yang terdiri dari warna hitam dan putih maka selanjutnya dilakukan image thinned, yaitu dengan membuat sebuah pola yang berbentuk garis berdasarkan pola terang yang terbentuk dimana dari hasil pola tersebut nanti akan menghasilkan sebuah hasil pengukuran yang mengacu kepada jarak antar garisgaris yang terbentuk dalam arah horisontal dan vertikal. Image thinne dapat kita lihat pada gambar 14 [7].

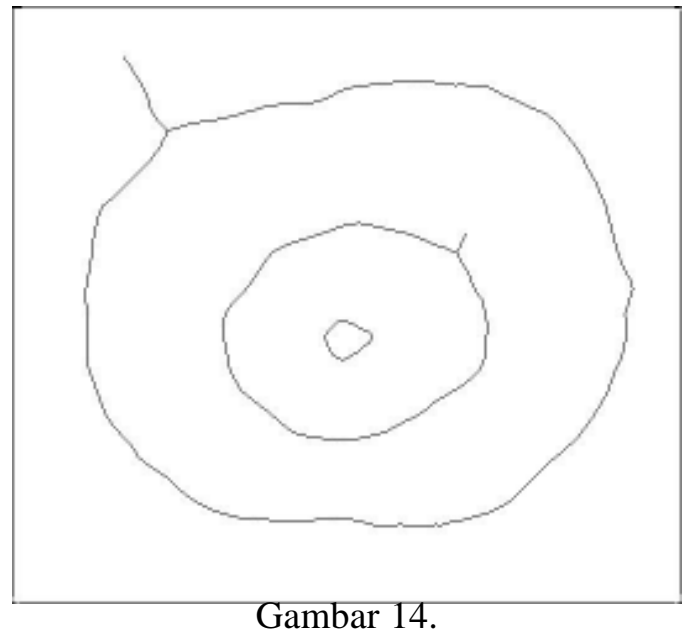

Image Thinned Untuk Displacement

$$
1,5 \mathrm{~mm}
$$

Dengan menggunakan persamaan [15] maka dari gambar 14 diperoleh nilai medan deformasi pada plat.

\section{HASIL DAN PEMBAHASAN}

Untuk memvalidasi data yang dihasilkan antara metode numerik dan metode moire maka hasil pengukuran medan perpindahan yang dihasilkan diambil 4 buah titik yang masing-masing berjarak $1 \mathrm{~cm}$ mulai dari titik pusat (perpotongan diagonal plat) dalam arah horisontal menjauhi titik pusat tersebut.

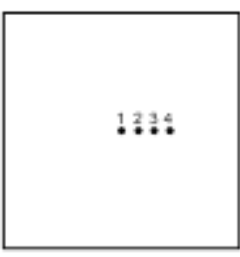

Gambar 15.

Titik-titik Validasi Data pada Plat Uji

\section{Menghitung Nilai Strain, Stress}

Dari hasil image thinned kemudian dengan menerapkan rumus:

$$
\varepsilon_{x}=\frac{p}{\delta_{x}} \text { dan } \varepsilon_{y}=\frac{p}{\delta_{y}}
$$

untuk mencari nilai strain maka nilai $\delta_{\mathrm{x}}$ dan $\delta_{\mathrm{y}}$ bisa kita ketahui dengan mengukur jarak antara garis moire tersebut di atas secara horisontal dan vertikal. Nilai p adalah jarak antara kisi yang divariasikan, sehingga dari persamaan strain tersebut dapat kita peroleh strain ekivalen yang terjadi pada plat tersebut dalam bentuk mesh adalah sebagai berikut:

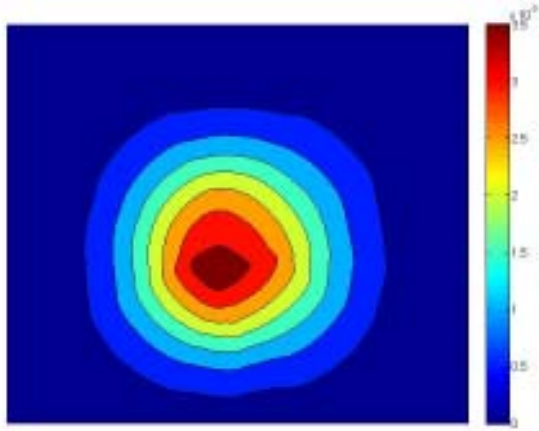

Gambar 16

Medan Strain Plat Untuk Displacement $1,5 \mathrm{~mm}$ 
Vol. 1, No. 1, Oktober 2013

Meshing pada plat dapat kita lihat pada gambar 4.16 di atas dimana warna merah menunjukkan daerah maksimum strain yang terjadi pada plat uji untuk beban pusat sebesar 1,5 mm dan jarak kisi sebesar $1 \mathrm{~mm}$. Dari hasil meshing tersebut maka dibuatlah kontour yang meliputi distribusi strain yang terjadi pada plat uji tersebut. Nilai strain terdistribusi pada plat semakin kecil mulai dari pusat pembebanan hingga ke tepi plat dengan nilai maksimum strain terjadi pada pusat adalah 0,005 .

Dengan menggunakan rumus hubungan stress-strain yaitu:

$$
\sigma_{y}=\frac{E}{1-v^{2}}\left(\varepsilon_{y}+v \varepsilon_{x}\right)
$$

maka didapatkan medan stress plat yang terjadi untuk pembebanan berupa displacement sebesar 1,5 mm.

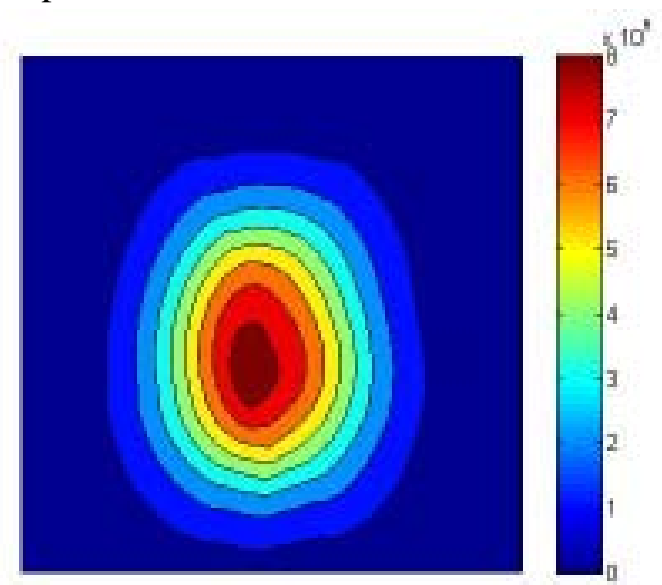

Gambar 17.

Medan Stress Plat Untuk Diplacement

Pusat $1,5 \mathrm{~mm}$

Gambar 4.17 memperlihatkan medan stress yang di alami oleh material pada saat pembebanan deformasi sebesar 1,5 mm diberikan di pusat. Stress yang terbesar terjadi pada pusat atau sekitar pembebanan dengan nilai maksimal adalah 8,58 x $10^{8} \mathrm{~Pa}$.

Tabel 5.2 Validasi Data Medan Stress

Untuk Displacement 1,5 mm

\begin{tabular}{|c|c|c|c|}
\hline Titik & $\begin{array}{c}\text { Numerik } \\
\text { Ansys }(\mathrm{Pa})\end{array}$ & $\begin{array}{c}\text { Metode Mbire } \\
(\mathrm{Pa})\end{array}$ & $\begin{array}{c}\text { Teori } \\
(\mathrm{Pa})\end{array}$ \\
\hline 1 & $8,93 \cdot 10^{8}$ & $8,59 \cdot 10^{8}$ & $8,34 \cdot 10^{8}$ \\
\hline 2 & $4,77 \cdot 10^{8}$ & $5,06 \cdot 10^{8}$ & $4,07 \cdot 10^{8}$ \\
\hline 3 & $2,48 \cdot 10^{8}$ & $2,87 \cdot 10^{8}$ & $2,51 \cdot 10^{8}$ \\
\hline 4 & $1,49 \cdot 10^{8}$ & $1,67 \cdot 10^{8}$ & $1,55 \cdot 10^{8}$ \\
\hline
\end{tabular}

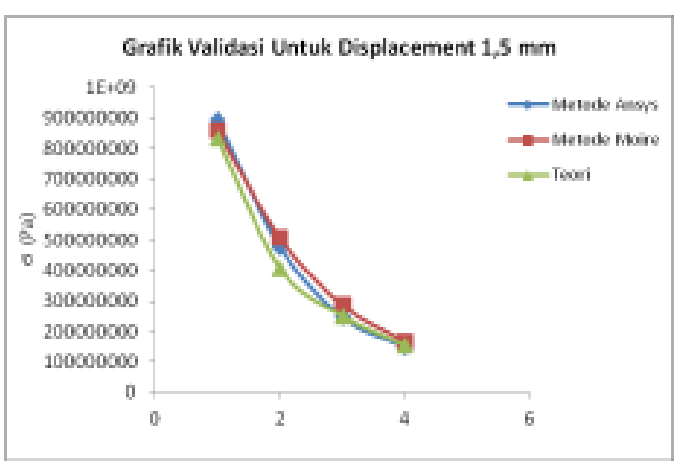

Gambar 18.

Grafik Validasi Medan Stress Displacement $1.5 \mathrm{~mm}$

Gambar 5.5 menunjukkan grafik perbandingan antara ketiga metode yang digunakan dalam menentukan besaran stress yang di alami oleh plat uji pada empat titik yaitu titik 1, 2, 3 dan 4. Validasi antara teknik pengukuran dengan menggunakan metode numerik dan metode moire terdapat perbedaan yang nilai rata-rata dari empat titik tersebut berkisar 7,5\% dan untuk metode moire dengan metode analitis teoritis $12,4 \%$.

\section{KESIMPULAN}

Berdasarkan hasil eksperimen yang dilakukan kemudian hasil pengukuran dengan menggunakan tiga metode yaitu metode numerik, metode moire dan metode teoritis diperoleh kesimpulan sebagai berikut: 
Hidayat A. Marlang, Teknik Pengolahan Citra Pengukuran Besaran Tegangan Regangan Plat Persegi Dengan Metode Moire’ Sebagai Salah Satu Alternatif

Pengukuran Dalam Desain Industri Manufaktur

- Besaran stress yang terjadi pada plat uji jika dibandingkan antara metode moire dan numerik terdapat perbedaan 9,4\% untuk pembebanan $2 \mathrm{~mm}, 7,5 \%$ untuk pembebanan $1,5 \mathrm{~mm}$ dan $7,2 \%$

- Sensitivitas pola moire terhadap displacement sangat besar sehingga dengan adanya variasi pembebanan yang diberikan berupa displacement pusat pada plat uji akan sangat berpengaruh terhadap pola gelap terang yang dihasilkan.
- Secara numerik, teoritis dan metode moire terdapat perbedaan hasil pengukuran yang antara lain disebabkan oleh kualitas pola gelap terang yang dihasilkan kurang maksimal sebagai acuan software Matlab untuk melakukan pengolahan citra yang akan menghasilkan hasil pengukuran.

\section{Referensi}

Ansel C. Ugural, Stresses in Plates and Shells, New Jersey Institute Of Technology, Second Edition, Mc Graw Hill, 1999.

D.Post, B. Han and P.Ifju, High Sensitivity Moire, Experimental Analysis for Mechanics and Materials, Springer Verlag, New York, 1994.

Durelli, A.J., Parks, V,J, Moire Analysis of Strain, Prentice Hall, INC Englewood Cliffs, New Jersey, 1970

Isaac Amidror, The Theory Of The Moire Phenomenom, ISBN-10 1-4020-5458-0 (ebook), Springer, 2007.

Marvin Ch. Wijaya \& Agus Prijono, Pengolahan Citra Digital Menggunakan Software Matlab, Penerbit Informatika Bandung, 2007.

Nugrowati, Aura Mimosa, Penerapan dan Perbandingan Teknik Proyeksi Moire Pencahayaan Tunggal dan Ganda Dalam Profilometri Tiga Dimensi, Thesis Magister Program Studi Instrumentasi dan Kontrol Program Pascasarjana Institut Teknologi Bandung, 2003.

Rinaldi Munir, Pengolahan Citra Digital Dengan Pendekatan Algoritmik, Penerbit Informatika Bandung, 2004. 